\title{
Homosexuality and South African Cinema
}

\author{
By Martin P. Botha \\ Spring 2003 Issue of KINEMA
}

The following is an excerpt from a larger manuscript HOMOSEXUALITY AND AFRICAN CINEMA, a co-operative effort of Dr Botha (CityVarsity, Film 8 Television and Multimedia School in Cape Town, South Africa) and Professor Dethier and Dr. Willemse at the Free University of Brussels.

IN A GLITTERING ceremony at the $49^{\text {th }}$ Berlin International Film Festival a full-length South African film, The Man Who Drove With Mandela won the Documentary Teddy Prize. It was rewarded for its unique contribution to gay and lesbian history and for bringing forward a challenging and politically engaging subject.

The Man Who Drove With Mandela was directed by Greta Schiller and researched by the co-writer of the outstanding compilation on South African lesbian and gay lives, Defiant Desire, namely Mark Gevisser. No other film in South African history chronicled the lives of lesbian and gays in the way Gevisser's documentary has done ${ }^{(1)}$. It is a semi-biographical portrait of Cecil Williams, who was being "chauffeured" by Nelson Mandela on the day the future President was arrested near Maritzburg.

Williams was a communist and African Nationalist Congress (ANC) activist. He was a dedicated campaigner and recruiter of ANC members, and he was also flamboyantly gay. Williams was well known in the Johannesburg of the Fifties, as a socialite and a successful director of plays that belonged to the great liberal tradition of the earlier part of the century. He directed some of the country's top actors in their youth, staging contemporary classics in the city's lost and forgotten Library Theatre. One indigenous work remains notable. Called The Kimberly Train - directed in 1959 - it was about a love affair across the apartheid divide. In those days, because theatres were segregated, the white actress playing a coloured woman darkened her make-up by a couple of shades.

The facts surrounding Williams's life during the Dark Years of apartheid in the fifties and sixties are conveyed to us via excerpts from a biographical one-man play performed by Corin Redgrave. It is filmed on a set, with highly theatrical lighting, and Redgrave's sensitive performance as Cecil Williams gives us a keen sense of this openly gay man.

These performed fragments are integrated within interviews with party activists, who worked closely with Williams, by his colleagues in the theatre, black and white, and by wonderful archive footage of South African history over the past 40 years, which contextualises Williams's life vividly. But it is not just the life story of Cecil Williams. It is a fascinating, deeply moving chronicle of how political and intellectual dissenters of the 1950s and 1960s lived and operated in South Africa. We glimpse the way the shebeens in the townships and the nightclubs worked, and how theatre in its unique way became a voice for the marginalised.

The film becomes a wonderful kaleidoscope of stories fitted vividly together but hinged on the fact that on the day Mandela was captured the comrade in the car with him was a white gay man, whose lifestyle was known to prominent leaders like Walter Sisulu and Mandela in the ANC and South African Communist Party. Albie Sachs, an ANC activist, told Gevisser during his research phase, that if one wants to understand why the older generation of ANC comrades are so receptive to the notion of gay equality in the constitutional debate one needs to go back and look at the role that Williams, a gay man and a communist, played within the liberation movement.

Gevisser's groundbreaking research into South African gay and lesbian lives forms the foundation of The Man Who Drove With Mandela and his book, Defiant Desire (cf. Gevisser \& Cameron 1993). One overwhelming conclusion in his research point to the fact that there is no single, essential "gay identity" in South African society. It also destroyed the claim that homosexuality is a bourgeois Western phenomenon which contaminates the purity of African civilization. Homosexuality exists and flourishes in so-called black communities and cultures, despite oppression. 
Homosexual experience, however, is unique in South Africa, precisely because of our history of racial division and subsequent resistance. Our gay identities have been formed by a long history of racial struggle, which is brilliantly depicted in The Man Who Drove With Mandela. Our gay identities were also deformed by an oppressive system, which classified us into those with freedom and those without (Gevisser \& Cameron 1993). Apartheid legislated whom we were, where we could live, with whom could we associate, and even what kind of sex we could have. Asserting a lesbian and gay identity in South Africa became a defiance of the fixed identities - of race, ethnicity, class, gender and sexuality - that the apartheid system attempted to imposture upon all of us.

By the mid-1950s, the times depicted by The Man Who Drove Mandela, gay subcultures existed in the major cities like Johannesburg, Cape Town and Durban. The rapid urbanisation of especially whites, offered urban gays and lesbians a way, away from their families and predominantly conservative home communities, to "come out" as part of a gay subculture. With the exception of Cape Town, where there had been a gay culture based in the Cape Malay communities, these subcultures were mostly white, male and middle-class. In South Africa's apartheid history, however, the move of whites into cities was parallelled by a system of black migrant labour: single-sex compounds, where men were divorced from home communities, basically created opportunities for homosexual encounters.

The end of the Second World War saw a larger percentage of single people living away from their families. Hillbrow, in Johannesburg, with its high-density accommodation, became an obvious neighbourhood for single people and many gays moved there. Lesbians, despite being ignored by anti-gay legislation in South Africa, experienced far greater pressure to remain closeted and had far fewer public meeting places than men. While women's organisations focused on workplace rights and the anti-apartheid struggle during the fifties and sixties, it didn't address issues of sexuality or situate itself within feminist ideology. Without a feminist movement and virtual no subculture to refer to lesbians found it more difficult than gay men to find a space (Gevisser \& Cameron 1993).

On the whole, lesbian social life at the time revolved around private parties in private homes, while white gay men had the opportunity to interact in pubs and public places such as parks or at the beachfront in Durban or Cape Town. Coloured gay men became very much the texture of District Six, a racially-mix neighbourhood in Cape Town, which was finally demolished by apartheid. A lot of activities was centred along Hanover Street, where many gay men rented rooms and socialised by going on "salon crawls" - visiting the many gay hairdressing salons. Gay life thrived in District Six, Athlone, Woodstock and Salt River, and a drag culture evolved here. Within the so-called coloured communities of Cape Town there were all-gay drag sports clubs, such as the District Six Netball Team, which participated in the women's' league. These netball teams, like the drag-performers, have been a constant in the Western Cape coloured culture, and have their latest incarnation in the Lavender Hill Netball Team, which was competing on the Cape Flats during the 1990s!

The history of gay life in Western Cape coloured communities is beautiful captured by two documentaries of Jack Lewis, namely Sando to Samantha aka the art of dikvel and especially A Normal Daughter: The life and times of Kewpie of District Six. Gay life has flourished over the years in these communities, probably since sexual dissidence is more tolerated in a hybrid, Creole society like that of South African coloureds than in supposedly coherent societies with strong patriarchal mythologies and traditions, like those constructed by the African and white Afrikaner nationalist movements in South Africa (Gevisser \& Cameron 1993). However, there was very little interaction between the coloured and white gay communities in Cape Town. And only in the 1980s did black men and women begin to play an active role in gay politics.

There is a long history that remains as yet unwritten of the repression and regulation of sexuality by the Apartheid State during its more than four decades holds on power. Out of fragments, sensational press reports and oral histories a historical researcher will probably one day reconstruct a narrative, which will deal with gay and lesbian oppression in South Africa as well. Racist legislation and iron-fisted rule have, since the earliest days of Nationalist Party rule, gone hand in hand with an obsessive interest in sexual policing. This policing was based on the values of Christian Nationalist apartheid ideology: the need to keep the white nation sexually and morally pure so that it had the strength to resist black communist onslaught. (Gevisser \& Cameron 1993). Sex laws drafted during the heyday of apartheid in the fifties and sixties prescribed tough 
penalties for a range of sexual offences. Apart from notoriously criminalising interracial sex, the Immorality Act of 1957 also made everything from prostitution, to soliciting for immoral purposes, to sex with mentally retarded persons illegal and punishable by prison sentences of up to six years. In 1985, the racial provisions of the Act were altered but its other provisions were kept intact.

Freedoms of sexual speech and association were virtually unheard of until the ANC-led government came into power in 1994. Before that historic event the South African Publications Board censored any representations of sex or any sexual views that stray too far from what is defined as moral within a narrow, conservative world view (Tomaselli 1989). In practice this means, among other things, that anything with the sole purpose of providing sexual stimulation - such as sexy pictures or writing - was undesirable and hence illegal. Even educational videos on safe sex practices for gay men experienced censor problems as late as the beginning of the 1990s!

Concerted attacks on the gay community in South Africa from the mid sixties consisted of occasional incidents of victimization and the launching of a vigorous legislative campaign against it. The trigger of the campaign was a police raid on a house in Forest Town in Johannesburg during January 1966, where 300 gay men were dancing and kissing. It was recommended to the Minister of Justice that laws should be tightened to combat homosexuality. The issue was taken to parliament. A select committee of parliamentarians was established, at the Minister's request, to look into the matter more closely. The report of this investigation, the only serious policy-making initiative to ever come from the Nationalist Party government on the issue of homosexuality, was published in 1968.

It stated that homosexuality was spreading because older men and women were seducing teenagers (Gevisser \& Cameron 1993). A gay action group, formed in the aftermath of the party raid, paid legal and expert witnesses to make representations. The anti-criminalisation lobbying was not wasted, since the committee was talked out of the idea of new laws aimed at gay sex in general. However the committee did go ahead with reactionary recommendations regarding gay parties and sex with teenagers. Any sexual acts between men at a party were to be banned, including kissing; the age of consent for male homosexual acts was to be raised from 16 to 19 years; and the manufacture or distribution of any article intended to be used to perform an unnatural sexual act was to be prohibited (Isaac \& McKendrick 1992). These recommended amendments to the Immorality Act were passed into law in 1969. Just after the legislation was passed a clampdown on outdoor meeting places for gay men, as well as routine police surveillance of gay clubs, bars and parties occurred, deep into the seventies and eighties.

Despite initial hostility the authorities agreed in 1990 to allow a lesbian and gay pride march through the streets in the metropolitan centre of Johannesburg. Censorship, however, regulated writing and audiovisual expression regarding gay lives until the first democratic government came into power in 1994. The censorship of gay material was before 1994 severe. Magazines, such as popular US gay journal The Advocate, and books widely available in other countries were regularly banned, simply because they assume that there is nothing wrong with being gay or lesbian. Lesbian and gay publishers and book importers faced an uphill battle for survival. Otherworld Books, an independent book company, based in Cape Town, and was but one example. Since it catered predominantly for the lesbian and gay market, it imported books on sexual theory, history, politics and culture. As late as 1992 Customs House in Cape Town confiscated every shipment of books bound for Otherworld, claiming possible contraventions of South African censorship laws (cf. Gevisser \& Cameron 1993).

\section{The South African film industry}

At the time of writing, it is sad to say South Africa still has a deeply fragmented film industry and virtually no national film identity. The reason for this fragmentation and lack of identity is multifaceted, each facet interacting to produce a complicated set of associations and relationships. Various academic scholars such as Pieter Fourie (1981) of Unisa, Keyan Tomaselli (1989) and John van Zyl (1985), as well as research teams within the industry, such as the Film and Allied Workers Organisation's (FAWO) Film Commission spent time in identifying and analysing the ills of our industry. Three books were published during the 1990s on the local industry, which also addressed the reasons for its collapse (cf. Botha \& Van Aswegen 1992; Blignaut \& Botha 1992; Botha \& Dethier 1997).

In 1995, cinema in South Africa was exactly 100 years old. Over 1,350 feature films had been made since 
1910. Early projection devices were utilised around the Johannesburg gold fields from 1895 onwards. The first ever newsreels were filmed at the front during the Anglo-Boer War (1889 - 1902). Forty-three films of good technical quality were made between 1916 and 1922 by IW Schlesinger's company, African Film Productions. Schlesinger, however, was unable to secure a foothold in either the British or United States markets for the screening of South African films.

A thirty years lull was broken in the 1950s by Jamie Uys who succeeded in attracting Afrikaner-dominated capital for independent production. He was instrumental in persuading the Nationalist Party government to provide a subsidy for the making of local films. Indirectly this step led to the severe fragmentation of our film industry.

\section{Reasons for the fragmentation and lack of national identity}

In a nutshell, one could say that the apartheid policy as well as ineffective state-subsidised film structures have contributed to the severe fragmentation of our film industry (Nathan 1991; Tomaselli 1989). Since 1956 and the introduction of a regulated subsidy system, government and big business have collaborated to manipulate cinema in South Africa. Ideology and capital came together to create a national cinema that would reflect South Africa during the Verwoerdian regime of the sixties. However, it was initially a cinema for whites only, and predominantly Afrikaans. Of the 60 films made between 1956 and 1962, 43 were in Afrikaans. Four were bilingual and the remaining 13 were English. The subsidy system rewarded box-office success. Once a film had earned a specific amount of money at the box-office, it qualified for the subsidy, which paid back a percentage of costs. This percentage was initially higher for Afrikaans films than for English productions. It is therefore evident that the government of the day realised the potential influence this Afrikaner-dominated industry would have on the growth and spread of the Afrikaans language. Since 1962, Afrikaner capital became a significant factor in the industry when the insurance company SANLAM acquired a major interest in Ster-films, a distribution company with the explicit intention to provide cinema predominantly for Afrikaner patrons. By 1969, Satbel (the Suid-Afrikaanse Teaterbelange Beperk) was formed, and the financing, production and distribution of films in South Africa were now virtually in the hands of one large company (except for a few cinemas owned by CIC-Warner). The white Afrikaans audience for the local cinema was relatively large and very stable, guaranteeing nearly every Afrikaans film a long enough run to break even as long as it provided light entertainment and dealt with Afrikaner reality and beliefs (Davies 1989; Tomaselli 1989).

With a few exceptions, the films were unremarkable. Fourie (1981) attributes this to the conservative attitude of Afrikaners at that stage towards the films. Afrikaners wanted their ideals visualised in these films. This idealistic conservatism was characterised by an attachment to the past, to ideals of linguistic and racial purity and to religious and moral norms. Homosexuality had no place in this world view. The films had to subscribe to these conservative and homophobic norms in order to be successful at the box-office. The films seldom attempted to explore a national cultural psyche. As such, they were a closed form, made by Afrikaners for Afrikaners, with little or no attention to their potential to say something important about their society to an international audience. The type of realism that could have analysed Afrikaner culture in a critical manner was avoided. Instead use was made of folk stereotypes that showed the Afrikaner as chatty, heart-warming and lovable in a comedy tradition, or as beset by emotional problems that had little to do with society, but much to do with the mainsprings of western melodrama about mismatched couples overcoming obstacles on the path to true love (Blignaut \& Botha 1992). Afrikaans characters were always heterosexual, and although a film like Forty Days hinted at the "perverse" homosexual subculture of Hillbrow, it remained virtually unsaid. Another film, Seuns van die Wolke, presented audiences with vague homoerotic images of half-naked men, but nothing daring was portrayed. Afrikaans-language films ignored the socio-political turmoil, as well as the realities experienced by black South Africans under apartheid.

Fourie (1982) argues that most Afrikaans films communicated by means of obsolete symbols that had little intercultural communication value. They painted a one-sided and stereotypical portrait of the Afrikaner, leading to a misconception about who and what the Afrikaner was. Furthermore, the negative portrayal of blacks as a servant class in these films is a visual symbol of the deep-seated apartheid ideology.

The films by Jans Rautenbach and Emil Nofal, namely Die Kandidaat, Katrina and Jannie Totsiens, were successful alternatives to the numerous Afrikaans escapism fare of the 1960s and early 1970s (Botha \& Van 
Aswegen 1992). After the introduction of South African television in 1976, some Afrikaans filmmakers such as Manie van Rensburg made brilliant dramas and series for local television. In fact, Van Rensburg became a chronicler of the Afrikaner psyche in revisionist dramas such as Verspeelde Lente and Die Perdesmous. But even in Van Rensburg and Rautenbach's universes, homosexuality didn't exist.

The Afrikaans film, with a few exceptions such as Rautenbach's Broer Matie, Johan Blignaut's Mamza and Katinka Heyns's Fiela se Kind, Die Storie van Klara Viljee and Paljas, including television dramas and series like Veldslag (1990), stagnated during the past three decades and even disappeared in the 1980s and 1990s. However, openly gay or lesbian characters are totally absent in these highlights of the Afrikaans film industry. In the year 2002, the Afrikaans film has to adapt to the drastic changes in South African society, or else become totally irrelevant when their themes are measured against the viewers' own experience (Blignaut \& Botha 1992).

Afrikaans cinema and television haven't yet offered viewers any three-dimensional gay characters. In the comedy Lipstiek Dipstiek the two gay characters (in supporting roles) are a stereotyped, flamboyant sissy and a villainous yuppie, which ended up with each other. In Kaalgat tussen die Daisies drag queens in an "unrecognizable gay pub" are appearing before old heterosexual men with no gay men in sight and the leading gay character turned out to be an undercover cop, which is playing gay as a drag queen to finalise a case! Leon Schuster's slapstick comedies (There's a Zulu on My Stoep, Short 'n Sweet, Panic Mechanic) are full of homophobic and derogatory fag jokes and references. In our most popular daytime television soapy, Egoli, only recently gay characters were introduced.

Another contributor to the fragmentation of the national film industry was the creation of a so-called Bantu film industry during the 1970s. This boost to black films resulted in the making of a large number of shoddy films in ethnic languages that were screened in churches, schools and community and beer halls. It was contrary to government policy to allow black cinemas in the urban white areas, as this would concede the citizenship of urban blacks. The urbanisation of blacks was portrayed as uniformly negative and homeland life as more fitting (Gavshon 1983; Van Zyl 1985). At this stage, black and white audiences were treated differently. The audiences were separated each with its own set of rules and operations, films and cinemas. Any film that managed to be made which in any way reflected the South African society in turmoil, was banned by the state, or received no distribution whatsoever, and thus did not qualify for any film subsidy. A true national film industry did therefore not develop through the Bantu film industry - only a few inferior paternalistic films for blacks were made, chiefly by whites. Gay and lesbian characters didn't exist in these films.

During the mid-1980s the industry was further fragmented. By means of substantial tax concessions that made investing in film an attractive option, a boom occurred in the commercial industry (Accone 1990-a, 1990-b; Powell 1990; Schoombie 1990; Silber 1990-a, 1990-b; Blignaut \& Botha 1992). Several hundreds of films were made, mostly inferior imitations of American genre films (Blignaut \& Botha, 1992). The majority of these tax-shelter films did not reflect any recognizable socio-political reality or national culture. At the end of the 1980s, the tax-shelter scheme collapsed and this industry was virtually wiped out.

The history of film distribution in South Africa has sadly been one of racism and segregation (Tomaselli 1989). Only in 1985 did the distributors manage to desegregate some cinemas, and for the first time the existence and importance of the majority of South Africans, deprived both socially and economically of the chance to be part of a cinema-going public, were acknowledged.

Ster-Kinekor and Nu Metro, as well as United International Pictures control the distribution of films in South Africa. In contrast to these three giants, independent cinemas are largely second-run cinemas (screening films that have already played the major networks); playing double-bill shows, at minimal ticket fares. There were approximately 202 independent cinemas in South Africa during the 1990s and some were in the process of closing down (Blignaut 1990). The independent cinema of the 1980s which was critical of apartheid and which received international acclaim was chiefly distributed through the independent venues. The independent theatres however did not qualify for state subsidy regarding box-office income. The filmmakers of films critical of apartheid seldom see their work being distributed by the main distribution companies. In fact, American imports dominate the mainstream networks, up to $92 \%$ of screen time. Films such as Jobman, Mapantsula, Windprints, On the Wire and several other examples of the independent film revival of the 1980s 
were seldom seen by the majority of South Africans. This part of the local film industry has been forced to become something of an export industry although it dealt with the realities of blacks in this country (Bauer 1987; Botha 1990; Botha \& Burger 1989; Botha \& Van Aswegen 1992). Cinemas were predominantly built in "white areas" leaving the "black areas" such as the townships virtually without cinema outlets. Less than 4 million people out of a population of 44 million are annual cinemagoers.

The film movement of the 1980s and partial unification within the industry during the 1990s In many respects, the early 1980s signified an opening-up for South Africa, socially as well as politically. At the beginning of the decade, President P. W. Botha began instituting a "reform" programme (which was balanced with heightened repression) and, in the aftermath of the Soweto upheavals in 1976, a massive upsurge of black liberationist activity swept through the townships. For the very first time since the Nationalist Party came to power in 1948, there was a tangible sense that the decades of white Afrikaner Calvinist rule were coming to an end, and that the strict apartheid packaging off of people would give way to a more liberated and integrated society (Gevisser \& Cameron 1994). Those years, despite two States of Emergencies, saw the beginnings of deracialisation and the establishment of anti-apartheid countercultures, which questioned, vociferously, the religious and political restrictions of the previous forty years. Within gay politics gay movements such as LAGO (Lesbians and Gays Against Oppression), which became OLGA (Organisation of Lesbian and Gay Activists), as well as black gay activist Simon Nkoli's GLOW (Gay and Lesbian Organisation of the Witwatersrand) became part of the broad democratic movement.

Since the late 1970s and the early 1980s a group of film and video producers who were not affiliated to the established film companies in the mainstream industry, made films about the realities of the majority of South Africans (Botha \& Van Aswegen 1992). Most of the films were shown at film festivals, universities, church halls, trade union offices and the private homes of interested parties. Most of the films experienced censorship problems during the State of Emergency. The films had small budgets and were either financed by the producers themselves, by progressive organisations or with the assistance of the tax-benefit system of the 1980s (Tomaselli 1989). The films were chiefly the product of two groups that emerged jointly: a group of white university students opposed to apartheid, and black workers who yearned for a film form using indigenous imagery that would portray their reality in South Africa, that would give them a voice and space in local films.

This remarkable process of intercultural communication led to a mass movement of workers, students and members of youth, sport and church organisations who united in their opposition to apartheid. The production of audiovisual material, forms of communication that required specialised production skills and money not necessarily found in the black worker class, was a further indication of the process of intercultural communication that was taking place. This process contributed to the formation of FAWO in September 1988. One of the aims of FAWO was to unite all filmmakers within South Africa to establish a democratic society (Currie 1989; Metz 1990).

Together with numerous documentaries, community videos and the rise of short fiction and animation film making, full-length films such as Mapantsula marked the beginning of a new, critical South African cinema. Botha and Van Aswegen (1992) referred to this cinema as the alternative film movement of the 1980s. It is evident that this new cinema is based on audiovisual material that reflects the realities of the black majority. It constitutes a valid part of our national film industry. It is from these films that the symbols and iconography of a national film industry can be drawn, rather than from the diversions produced by the Afrikaans cinema, the Bantu film industry and the tax-shelter films discussed in the previous section.

Approximately 944 features were made in South Africa in the period 1979 to 1991, as well as nearly 998 documentaries and several hundred short films and videos ( Blignaut \& Botha 1992). Although most of the features were of mediocre value, at least 20 to 30 remarkable indigenous local feature films were made. They included Mapantsula (which participated in the Un Certain Regard section at Cannes), Marigolds in August (a winner of two Silver Bears at Berlin), On the Wire, the brilliant The Road to Mecca (which was highly applauded at film festivals in India and Canada), the interracial drama Saturday Night at the Palace, the Mannheim Jury Prize Winner Shotdown, the evocative Afrikaans dramas Fiela se Kind and Die Storie van Klara Viljee, Manie van Rensburg's four hours director's cut of The Fourth Reich about Afrikaner nationalism, and the Darrell Roodt trilogy (Place of Weeping, The Stick and Jobman). Since 1991, 
co-productions have lead to six local films receiving international attention: Darrell Roodt's Sarafina! and Cry, the Beloved Country, Elaine Proctor's Friends; Les Blair's Jump the Gun; Shyam Benegal's The Making of the Mahatma; and Katinka Heyns's Paljas. Unfortunately, not any of these quality productions featured gay or lesbian characters.

Although apartheid was officially still in place during the making of films such as Mapantsula, Jobman, On the Wire and The Stick, these features, together with numerous community and resistance videos became vital instruments in the anti-apartheid struggle. Three major elements of these features were that

- They were produced by means of co-productions with or solidarity assistance from progressive nonSouth Africans;

- South Africans were significantly involved in most if not all spheres of production as opposed to Hollywood films on apartheid; and

- the exhibition and distribution of these films, especially the community videos and documentaries on the evils of apartheid were one great problem area.

Mapantsula and The Stick, for example, were only un-banned after 1990, and Jobman has still not been commercially released in our country. Most of these films were screened at alternative venues like community halls, churches in the townships, selected progressive film festivals and even at private homes.

As mentioned previously, it is from these films that the symbols and iconography of a national South African film industry can be drawn, although many questions regarding a national cinema ought to be addressed in future debates. These films can be described as progressive film texts in the sense that all of them are consciously critical of apartheid, either in a historical (Fiela se Kind, Jobman) or a more contemporary context (the South Africa of the 1980s in Mapantsula). They deal with the lives and struggle of the people in a developing country and are mostly allied with the liberation movements for a nonracial South Africa.

Mapantsula is an example of local film making that represents a voice of resistance, which echoes in the popular culture, and memory of the majority of South Africans. The existence and experience of township life was severely censored and withheld from the media before 1990. The workings of the Publication Control Act, coupled with the State of Emergency and the regulations accompanying it, were just two of the more obvious means to achieve this media silence. Features such as Mapantsula, Jobman and On the Wire were a critical and necessary intervention in the representation of this usually hidden reality on South African screens. These films, like the short film, Come See the Bioscope, try to recover popular memory. They deal with events, which were conveniently left out in official South African history books or in a contemporary context in actuality programmes on national television. Therefore, they became guardians of popular memory within the socio-political process in our country.

The films examine the South African reality critically. Existing myths and stereotypes associated with apartheid have been questioned, examined and their falseness revealed. South African reality is observed mainly from the viewpoint of black South Africans. For too long many whites in this country have ignored the values and norms of their fellow South Africans. In this respect the new critical cinema is meaningful for intercultural communication and intercultural relations: on the one hand it offers to South Africans who are opposed to apartheid a voice and space; on the other hand, many whites, who are accounted part of the status quo of apartheid, are given the opportunity of familiarizing themselves with people who belong to other cultures and ideological groups and who have, due to racial segregation, different spheres of life.

A positive development during the early 1990s was the perception from all sectors of the industry that cinema has a vital role to play in the forging of social cohesion and the process of democratization and development that so urgently needs to take place. In 1991 the Film and Broadcasting Forum (FBF) was established to address the problems of the industry. It was widely considered to be an important step in the consultation process that resulted during in the creation of a single body during 1993, motivated by mutual interests. In composition, the FBF represented the widest possible cross section of industry interests, from producers through to directors, writers, actors, musicians, technicians, agents, managements and studios. It also included both progressive and more establishment-oriented groupings, some of which have hitherto not been overly co-operative. 
The FBF described its prime objective as the creation of an environment in which its members could address strategic issues of common interest and to discuss such strategies with the state, political parties, cultural groups, broadcasters, distributors, exhibitors and others. The main aim was the establishment and development of a representative and indigenous South African film culture which would redress the political imbalance of the past to ensure equal access for all South Africans to film structures. From this consultative process, an interim consensus document emerged which tried to address the restructuring of the local film industry.

This resulted during 1993 in the creation of the Film and Broadcasting Steering Committee, representing the eight major film organisations in local cinema. The Film and Broadcasting Steering Committee painstakingly worked on proposals for a South African Film Foundation for more than a year. The proposed structures were modelled on the French film structures in France and Burkina Faso. By mid-1994 the Film and Television Federation emerged from the Broadcasting and Film Steering Committee.

Another important development was the historic democratic elections of 1994 . The year 1994 could also be regarded as a landmark for the South African film industry. A comprehensive study by the research institution, the Human Sciences Research Council (HSRC), into the restructuring of the entire South African film industry was completed and forwarded to the newly formed Department of Arts, Culture, Science and Technology (see Botha et al. 1994). The report of 400 pages received widespread praise throughout the local film and television industry. The HSRC research team recommended that state aid to the local film industry should be administered by a statutory body referred to as the South African Film and Video Foundation (SAFVF). Commercial viability should not be the sole criterion for government support of locally made films. All types of films, including short films, should benefit, and a developmental fund should be used to support first-time filmmakers from previously marginalised communities. A Government-appointed Task Group extensively used this report during 1995 to draft the White Paper regarding a post-apartheid film industry. The White Paper was completed by 1996 and the National Film and Video Foundation Bill was accepted by Parliament in 1997.

In March 1995, the old South African film subsidy system, which was based on box office returns, finally ceased to exist, and an interim film fund became in operation. Ten million rands were annually distributed among various projects, which included funding for short film-making. In 1998, for example, R 110,000 was allocated to the development of short films and R 1,010, 000 for the actual production of short films These grants had an important impact on the film industry.

A fascinating development is the rise in local short film production. In the beginning of the 1990s films such as Sales Talk and the animation work by William Kentridge; Sacrifice, about the disintegration of an Afrikaner family and Guy Spiller's The Boxer, about white working class fears regarding political change in South Africa, stunned audiences. During 1993, 37 short films were screened at the Mail/Guardian film festival. Catherine Meyburgh's The Clay Ox, about white South Africans trying to redefine their role in an apartheid society and to come to terms with their heritage, gave new hope for another revival in innovative local film making.

During the mid 1990s further developments within the local film industry stimulated the production of especially short films, a significant development in the growth of the local film industry. The pay-television station M-NET initiated a project entitled NEW DIRECTIONS to give talented first-time South African and other African filmmakers and scriptwriters a break into the film industry. By 199818 short films and two features were completed by M-NET. This project is a showcase for new talent in this country, and has led to some outstanding short films such as Come See the Bioscope, Angel and Salvation. Firsttime directors and screenwriters, some of them female, black or "coloured", explored a diversity of themes. Director Khalo Matabane and scriptwriter Mtutuzeli Matshoba, for example, created an award-winning comedy Chikin Biz'nis about the vibrant South African informal economic sector, which provides millions of unemployed urban South Africans with alternative livelihood. Russell Thompson and Patrick Shai explored South Africa's culture of violence respectively in The Pink Leather Chair and Stray Bullet, while directors Dumisani Phakathi and Tamsin McCarthy highlighted intimate relationships against the background of the new South African democracy respectively in An Old Wife's Tale and Cry Me A Baby. Relevant social problems such as drug abuse (Stimulation) and abortion (The Apology) were also explored in these M-NET 
short films.

Regional initiatives further encouraged short film production. The Cape Film and Video Foundation and the South African Scriptwriters Association (SASWA) in collaboration with the Department of Arts, Culture, Science and Technology funded three short films, entitled Kap an Driver, a beautiful exploration of racial relations in the "new" South Africa; On the Rocks, about an affluent white man's encounter with Cape Town's homeless people; and Stompie and the Red Tide, also about Cape Town's homeless. The Southern African International Film and Television Market (Sithengi), held every November in Cape Town, has become an important forum for locally made features and short films

Sithengi 1998 highlighted an important Pan-African short film initiative, called African Dreaming. The array of six short films is a major co-production, the first of its kind on the continent, which draws on talent from Mozambique, Namibia, Senegal, Tunisia, Zimbabwe and South Africa. International funding came from the South African Broadcasting Corporation (SABC), the Hubert Bals Fund in the Netherlands, Cable channel La Sept/Arte in France, YLE TV2 in Finland, HIVOS and NCDO in Holland, the CNC in France, the French Ministry of co-operation and Video Lab in South Africa. Deals and contracts were co-ordinated by one of South Africa's leading producers, Jeremy Nathan, through his company Catalyst Films. The South African film, Mamlambo, a love story between a black boy and a Chinese girl, gave first-time female and black director, Palesa Nkosi a chance to direct a film. In many ways short film-making in South Africa provides previously marginalised voices a voice...

Most of the short fiction and non-fiction films during the early 1980s were political texts, which were instruments in the anti-apartheid struggle. Only later during the 1980s other themes were explored by various marginalised filmmakers, for example gay and lesbian equality within South Africa's conservative and homophobic society. Current post-apartheid cinema is very much a cinema about marginalised people, e.g. the homeless of Cape Town in a documentary like Pavement Aristocrats: The Bergies of Cape Town or the short M-NET fiction film, Angel, which deals with a homeless couple.

At the $3^{\text {rd }}$ Southern African International Film and Television Market, as well as at the $22^{\text {nd }}$ Cape Town International Film Festival the real strength of this post-apartheid cinema was clearly demonstrated. Our short films and documentaries, which have won numerous international awards during 1998 and 1999, overshadowed our attempts at feature filmmaking.

Apart from the multi-award winner The Man Who Drove With Mandela, audiences were impressed with Zola Maseko's The Life and Times of Sara Baartman, which deals with the tragic true-life story of a young South African woman who was taken to Europe and exhibited as a freak in London and Paris in the early $19^{\text {th }}$ century. Maseko's short film, The Foreigner, a heartbreaking indictment of current xenophobia in South Africa, also won various international awards, including a second prize at the Festival di Cinema African in Milan.

Among the other short films, Gavin Hood's The Storekeeper stood out. It is a devastating portrait of the culture of violence in this country. Without relying on dialogue Hood tells the story of an elderly man who owns a small, isolated shop in rural South Africa. After several burglaries he took the law in his own hands - with shocking consequences. Hood's film won as overall best short film at the Nashville Independent Film Festival. It also won the bronze for best dramatic short at the Houston International Film Festival.

The small renaissance in documentary and short films was made possible by funding from the Department of Arts, Culture, Science and Technology. During 1999 more than R2 million from the Interim Film Fund was allocated to the production of documentaries. Short films received more than R1 million. Prospects for future feature filmmaking look positive. The National Film and Video Foundation, which will support and promote the local film industry, was finally established and a council of fourteen members was appointed during April 1999. On a regional level, the Cape Film Commission has been established in order to promote and market the film industry within the Western Cape, which has become a vibrant base for short and documentary filmmaking, as well as commercials.

But despite the positive changes in the film industry, a new constitution which prohibits discrimination against gays and lesbians, as well as a strong gay movement in the form of the National Coalition for Gay and Lesbian Equality, our images of gay men and women are limited and still on the margin of the film 
industry. One ends up with less than ten short films, a few documentaries, less than five features with openly gay and lesbian characters and virtually no television programmes. The remainder of this section on South African cinema deals with these marginal images of gay and lesbian lives.

\section{An emerging gay cinema?}

Under apartheid many voices were silenced and marginalised in the film and television industries: blacks, women, gays and lesbians. During 1989 Melanie Chait's Out in Africa became the first South African film to deal with the gay and lesbian liberation struggle in South Africa. This short film is a moving tribute to two gay South African men, Simon Nkoli and Dr Ivan Toms who were respected internationally for their stand against apartheid. Dr Toms was the first white South African to refuse to serve in the South African defence force. Simon Nkoli was one of the Delmas trialists.

The film portrayed what it meant to be gay under apartheid and claimed that the South African liberation struggle is a movement for political as well as gay equality. Nkoli was arrested after a rent boycott demonstration in his home-township of Sebokeng and held in custody for two years before being charged, with 21 other prominent United Democratic Front activists, with treason. He became a cause celebre after his arrest: the confluence of his open homosexuality and his imprisonment as a soldier against apartheid made him immensely appealing to liberation-oriented gay organisations around the world. In Canada the Simon Nkoli Anti-Apartment Committee became a critical player in both the gay and anti-apartheid movements. Gay filmmaker John Greyson directed a short Canadian film, A Moffie Called Simon, which became a confirmation of solidarity with the jailed activist.

Through Nkoli's imprisonment progressive members of the international anti-apartheid movement were able to begin introducing the issue of gay rights to the ANC. The highly respectable Anti-Apartheid Movements of both Britain and the Netherlands took up Nkoli's cause, and this was to exert a major impact on the ANC's later decision to include gay rights on its agenda for a democratic South Africa. By 1986 Nkoli was formally charged with murder, but acquitted during the ensuing trail.

In Beverley Palesa Ditsie and Nicky Newman's Simon E I Nkoli's relationship with fellow activist Beverley Ditsie is portrayed. It's a moving story of their battle against prejudice in any form, an effort which played an important role in ensuring constitutional protection of gay rights.

Even more remarkable is Brian Tilley's It's my life. Shot over five months, this co-production with France, chronicles the activist activities of Zackie Achmat. He took on the world's largest pharmaceutical companies and the South African government, fighting to ensure affordable treatment for people living with HIV. Initially his organisation, the Treatment Action Campaign, joined the South African government in a court case against pharmaceutical companies hoping to facilitate a legal framework allowing for affordable antiAIDS medication, but victory in court results in disappointment as our government refused to act on the advantages afford by the win. Zackie, himself HIV positive, stunned the world by refusing to take medication as leader of the TAC because of his moral convictions: Four years ago he took a controversial stance that he would not take anti-retroviral drugs until our government set up pilot anti-retroviral programmes at community clinics in all of South Africa's nine provinces. At the time of writing Achmat was treated for opportunistic infections. In a report, Achmat summed up his determination to continue: "I intend living longer than Thabo Mbeki. I don't intend losing this fight..."

\section{Luis DeBarros}

An important new voice in the creation of a South African gay and lesbian cinema is Luiz DeBarros. Most of his short films were screened at the short film competition of the Weekly Mail Film Festival. Barros was a third year BA student at the University of the Witwatersrand when he made Pretty Boys, a film about two male prostitutes discussing their lives. The film attempted to explore the possibility of prostitution as a positive experience.

Clubbing revolved around six, twenty-something year old friends who meet one evening before they go out clubbing. With the film DeBarros captured the decline of a white ruling class in a society in which the rules are changing. They must come to terms with a future of uncertainty, a future no longer assured of privilege. Among the characters is an attractive gay male couple, who comes across as three-dimensional characters. They were probably the first non-stereotypical male gays on South African screens. 
DeBarros' latest short film is Hot Legs, a revenge fantasy, which revolves around Tim, a young gay doctor who wants to take revenge on Dave, a man he once loved, by holding him captive in a motel room for six days. Together the two characters relive their past and look at how they became the people they are. Although psychological troubled both characters are attractive, non-stereotypical gays. They are not falling in the traps of either being sissies or villains, just two human beings trying to sort out their conflicts within a homophobic society.

Since the late 1990s DeBarros is working on a feature on male homosexuality in South Africa, Pressure, but due to funding problems the end result has yet to be seen...

\section{Jack Lewis}

One of the most important local gay filmmakers is Jack Lewis who won acclaim for his two oral histories of gay subcultures in Cape Town. Lewis' A Normal Daughter: The life and times of Kewpie of District Six depicts gay life in the former District Six through the memories and snapshots of the main character, a drag queen. In District Six gays were an accepted part of a racially and religiously diverse community. Long before the emergence of the post-Stonewall gay scene in Cape Town life in District Six was open and out. From the main protagonist's hairdressing salon the gays organised elaborate drag balls, cabaret performances and concerts. They colonised clubs, prepared food for weddings and funerals, styled everyone's hair and looked after the neighbours' children. Lewis captures this vibrancy lovingly by means of a collection of snapshots and interviews. But sadly, Cape Town's District Six was physically destroyed by the apartheid government in the 1970s.

The sense of loss is also sensitively depicted in another oral history by Lewis, entitled Sando to Samantha: aka the art of dikvel. The video combines interview material with dramatised footage to reconstruct the life of Sando Willemse, a drag queen, who served in the South African Defence Force until he was dismissed because of his HIV status. He turned to prostitution to survive and found friendship and support in a community of drag queens working Cape Town streets. He died of HIV related causes in 1996 aged 22 years. Lewis allowed Sando to narrate his own story in a beautiful blend of moving personal testimony and subversive commentary on South African politics.

Lewis is also the founder of the South African Gay and Lesbian film festival. It started because he was active with the forming of ABIGAIL (Association for Bisexuals, Gays and Lesbians), the first black-led gay organisation in Cape Town. It was always a majority black run organisation. It did not attract many whites. To raise money for the organisation he started taking some of the video's that he had and showing them at places like Jazz Art and Don Pedro's... What he found was that the white gays from affluent "Camps Bay, Bantry Bay and Clifton were prepared to roll up to Jazz Art and sit on the bloody floor on crates to watch gay movies /Queer movies, on a video projector and stay around for a drink and so-on" (Peach 1999). Lewis stated in an interview with Peach during 1999:

I must say that in that period there was a special atmosphere broadly round in South Africa at that time and it got even to this type of A gay set. Today I think that they are more than ever-sunk back into their self-satisfied, self-congratulatory complacency where they bitch and moan about South Africa at every level and do fuck-all and are generally a pain in the gat for everybody. But at that time the whole anti-apartheid movement, the internal pressure of the $\mathrm{ANC}$, the movement in the country, what was happening in negotiations, even they, and I think they must be one of the most inert layers of society imaginable, despite their Queerness, were kind of moved. Everything was kind of special at that time and bathed in a special rainbow aura and nothing was quite real.

It was a revolutionary moment in its own way, although the revolution was a very muted one, in terms of what had originally been envisaged for South Africa, but none the less, the enormity of what was happening, the former government voluntarily surrendering power, got to people, and at the Queer level people felt that something was happening. They came out to these festivals and mini-programs and stayed all afternoon....and sat down and talked...

It was those screenings, of which there might have been half a dozen or more... that gave the impetus to form the formation of the festival. I raised a grant of R30,000... and I started 
organising the first film festival on my own and it was only at that point that Nodi [Murphy] actually joined me, about a month away the opening. She had much more film festival experience and provided that critical input which I think was what made the first festival such a success. (Interview with Peach 1999)

The first Out in Africa Gay and Lesbian Film Festival took place in South Africa in 1994, just after the new government came into power. The event was captured vividly by American lesbian director, Barbara Hammer, in her documentary Out in South Africa, which became one of the first local media portrayals of black gays and lesbians. The media silence regarding township gays were finally shattered.

Jack wants to create a black audience for the festival by promoting gay films to township gays and lesbians. "It will be a small audience to begin with but it will be an audience of their friends, family, organizational contacts, to come along and see what [someone's] done. Because they know the director and they like him or her and he or she's a cultural figure for them. And the word will get out and next time he/she does a film the audience will be bigger and in that way we will build a black audience for our festival" (Interview with Peach 1999).

Jack has facilitated a postgraduate course, offered at tertiary institutions, which combine practical and theoretical aspects of gay filmmaking. Open to students of fine art and drama it will provide an insight into gay and lesbian identity and its public representation. International filmmakers touted to share skills include John Greyson, who has visited South Africa twice for the gay and lesbian film festival. With funding from the Royal Netherlands Embassy, the Gay and Lesbian Film Development Programme will be run at the University of the Witwatersrand in Johannesburg and at the University of the Western Cape in Cape Town. The emphasis will be the promotion of indigenous stories, told by a demographically representative group of gay and lesbian filmmakers:

I think that the rest of the world, as I've seen from the response to... Sando to Samantha is hungry for all these kinds of stories, because the rest of the world [want] a larger view of the Queer issues. People, when the stories are well told, are interested in ways in which Queer issues play in cultures other than their own, because it gives them a take on their own experience, the contrast, the difference as well as the point [s] of similarity. Western Queers are some of the most highly evolved self-conscious species in the world. Part of their self-consciousness is a consciousness of their similarities and difference with the rest of the world. You see in San Francisco the foreign movie nights are sold out, for that very reason (Interview with Peach, 1999).

\section{Other voices: Stephen Jennings, Helena Nogueira and Cedric Sundstrom}

Another new voice to a local gay cinema is Stephen Jennings. The Dress follows the chance meeting of two lonely people. It is a short film about an encounter between an oppressed young man and a lonely older man, shot in black and white. The boy is obviously a victim of "domestic violence" and after engaging in a sexual encounter with the older man, his male lover brutally removed him from the flat. But the encounter means the chance for further meetings, even a relationship, which can't be halted anymore by the abusive lover.

During the eighties two films were made with gay characters: Cedric Sundstrom's thriller, The Shadowed Mind, and Helena Nogueira's lesbian love story set against political turmoil in Southern Africa, namely Quest for Love. The latter starred two popular Afrikaans actresses, Jana Cilliers and Sandra Prinsloo. Prinsloo played Dorothy, a marine biologist. Cilliers played Alexandra, the political journalist. The film used flashbacks to create a rhythm between Alexandra's memory and her current self-discovery, climaxing in her reunion with Dorothy (cf. Blignaut \& Botha 1992). Voice over and letters are also used to suggest Alexandra's verbal control over experience and her analysis of the political and sexual worlds in which she finds herself. It is a complex structure, but Nogueira manages to create a film of emotional power, which also presents us with three-dimensional lesbian characters.

The film starts with the arrest of Alexandra and her lover, Michael, for accusing South Africa of military intervention in Mozania/ Mozambique. Alexandra emerges from prison year later, goes to Mozambique to stay with Dorothy and finds she has to wait two weeks for her friend's return. The two weeks gives Alexandra to reflect on her relationships, her ideological position, and her attempts to come at terms with Africa. Dorothy, on the other hand, has become an integral part of Africa through her deeds as biologist. 
While the one woman is experiencing conflicts regarding her role, the other is at ease with herself and her sexual orientation.

The flashbacks mostly concern discussions and arguments between Alexandra and Dorothy regarding the values of political activism against those of political common sense and pragmatism. Alexandra favours intellectual engagement. Dorothy chooses community involvement. (Blignaut \& Botha 1992). She returns to her home country to try and help the people with her scientific knowledge, ecological and humanitarian concern. Nogueira's portrayal of a lesbian love affair against the background of South Africa's military destabilization campaigns in neighbouring countries is one of the highlights of our cinema. More than ten years after its first release in 1988 it still comes across as a powerful and complex portrait of political and sexual themes within a contemporary South African setting.

Set in an extremely unlikely therapy centre for weird sexual malfunctions The Shadowed Mind offers images of full-frontal male nudity and homosexual behaviour among the inmates. Shot in disused railway warehouses in Pretoria director Cedric Sundstrom created a stylised horror movie. The script, however, was workshopped in the space of a week, which unfortunately led to weak characters and a very loose narrative structure. Dialogue was improvised, but is never really convincing. The film tries to suggest that the delineation between sanity and madness be blurred. Homosexuality, thus, is placed within that context.

The asylum becomes a microcosmic battlefield on which a war of emotions is waged between the inmates. In that respect Sundstrom is successful: an atmosphere of menace is maintained throughout the film and the style and photography is sometimes breathtaking. But the film can't escape the old psychoanalytical notion that homosexuality is an illness, and finally, the bisexual male character, which engages in sex with another male, is brutally murdered. Another statistic for Vito Russo's list of murdered gay characters in the cinema! (Russo 1987). Not surprisingly The Shadowed Mind was banned for general release or festival screenings during the 1980s in South Africa. It was never released commercially in South Africa and I only saw it illegally on video during the end of the apartheid years.

\section{Conclusion}

In November 1993, in the waning days of Nationalist Party rule, representatives of twenty South African political parties, including the ANC approved a draft constitution for a post-apartheid South Africa. The new constitution featured a Bill of Rights outlawing discrimination on the basis of a number of personal characteristics, ranging from race and gender to age and physical disability. It also included sexual orientation: South African gays and lesbians were at last considered as a part of this beautiful country. With countries like Britain and the United States were still far from enacting gay civil rights protections, in just a few short

years South Africa is leading the world with the most progressive constitution regarding gay and lesbian equality. While its neighbours such as Zimbabwe and Namibia are moving towards repressive government legislation regarding gays and lesbians we are, at least in metropolitan areas, enjoying our new freedom.

It is still a long way to create total equality, since remaining anti-gay legislation from the past needs to be removed, homophobia is still rife in rural South Africa and the townships, and the vast majority of the population still lives in dire poverty. The country will struggle for many years to come to address the imbalances left by apartheid, also within the film industry, which is still predominantly white. But at least we are better off than many of our African neighbours.

\section{Notes}

1. Another attempt was Apostles of Civilised Vice by Jack Lewis.

\section{References}

\section{Literature}

Accone, D. Salvation of SA film in 'better Govt funding'. The Star Tonight! 19 January:1-2, 1990b. 
Accone, D. Some see new film subsidy as disaster. The Star Tonight! 1 March:1 1990-b.

Bauer, C. Breaking the local no-sound barrier. Weekly Mail 2 April:21, 1987.

Blignaut, J. The distribution dilemma of local product, in Showdata Bulletin, 2nd volume, edited by J. Blignaut \& C. Metz, Johannesburg: Showdata, 1990.

Blignaut, J. \& Botha, M.P. (eds). Movies moguls mavericks: South African cinema 1979-1991. Auckland Park, Johannesburg: Showdata, 1992.

Botha, M.P. Probleme om oplewing in S.A. film. Die Volksblad 4 Januarie: 6, 1990.

Botha, M.P. \& Burger, F. A weathervane in uncertain winds. Weekly Mail 14-20 July:21 \& $24,1989$.

Botha, M.P. \& Van Aswegen, A. Images of South Africa: the rise of the alternative film. Pretoria: Human Sciences Research Council, 1992.

Currie, W. Film and video workers organise. South African Labour Bulletin 14(5):7-12, 1989.

Davies, J. S.A. Film: A brief history. ADA 6:32-33, 1989.

Fourie, P.J. 'n Struktureel-funksionele model vir die formulering van 'n Suid-Afrikaanse rolprentbeleid. D.Litt et Phil-proefskrif, Universiteit van Suid-Afrika, Pretoria, 1981.

Gavshon, H. Levels of intervention in films made for African audiences in South Africa. Critical Arts 2(4):13$21,1983$.

Gevisser, M. \& Cameron, E. (eds). Defiant desire: Gay and lesbian lives in South Africa. Johannesburg: Ravan, 1994

Isaacs, G. \& McKendrick, B. 1992. Male homosexuality in South Africa: Identity formation, culture and crisis. Cape Town: Oxgord University Press.

Metz, C. FAWO, in Showdata Bulletin, volume 7, edited by J. Blignaut \& C. Metz, Johannesburg: Showdata, 1990.

Nathan, J. Movies and monopolies: the distribution of cinema in South Africa. Staffrider 9(4):61-84, 1991.

Powell, I. A snip off the old film subsidy scheme. Weekly Mail 2 - 8 March:21-22, 1990.

Russo, V. The celluloid closet: homosexuality in the movies. New York: Harper \& Row, 1987.

Schoombie, S. 'Die pasient is doodsiek'. Kalender, bylae tot Beeld 12 Februarie:2, 1990.

Silber, G. Tax, lies and videotape. The Executive June: 68-74, 1990-a.

Silber, G. Who killed the South African film industry? in Showdata Bulletin, volume 4, edited by J. Blignaut \& C. Metz, Johannesburg: Showdata, 1990-b.

Tomaselli, K.G. The cinema of Apartheid: race and class in South African film. Sandton: Radix, 1989.

Van Zyl, J. A reeling industry: film in South Africa. Leadership S.A. 4(4):102-106, 1985.

\section{Author Information}

Martin P. BOTHA is Associate Professor of Film and Media Studies at the University of Cape Town. He has published more than 200 articles, reports and papers on South African media, including six books on South African cinema. His most recent book is South African Cinema 1896-2010 (Bristol: Intellect, 2012). 